\title{
INDEX LIBRORUM PROHIBITORUM
}

\section{BY MARILYN RYE}

Ms. Rye is a student in the Graduate School of Library and Information Studies, Rutgers University

7 HE Index Librorum Prohibitorum, now no more than an historic document or series of historic documents, was once a powerful influence on the minds and lives of men. Yet this effort of the Roman Catholic Church to preserve its integrity against contamination from heretical writings by forbidding the reading of "dangerous books" was, perhaps, more decisive in its purpose than in its effect. As with any form of censorship, it influenced through restriction of the free flow of ideas; but also against its original purpose, by stimulating men to seek out ideas which circumstances otherwise would have consigned to oblivion. The history of the Index from its inception to its abolition traces the Church's changing position in an increasingly secular world from a dominant authority in a closed medieval world order to a more remote institution with diminished authority in the modern era. The Index was, perhaps, an effort by the Church to retain the universality of medieval Latin culture by promulgating a uniform code to set limits within which intellectual debate in Europe could take place. ${ }^{1}$ However, if this effort was doomed to failure, it would be a mistake to ascribe this failure only to the weakened influence of religious institutions, the growth of the secular state, a new diversity of world views, relaxed moral standards or a new attitude within the Church itself. While these causes all were present, the failure to impose the authority of the Index was inherent in the nature of the task the Church set itself. Could any office of the Church really have hoped to know and evaluate the contents of the endless stream of books that flooded Europe from the sixteenth to the twentieth centuries following the invention and establishment of printing? The history of the Index provides eloquent testimony to man's inability to keep pace with the technology he has invented.

Known familiarly as "the Index," the Index Librorum Prohibitorum

${ }^{1}$ T. S. Eliot, Selected Essays of T. S. Eliot (New York: Harcourt, Brace and World, Inc., 1964), p. 201 . Eliot believed that due to the universal use of Latin in Europe, "... medieval Latin tended to concentrate on what men of various races and lands could think together." 
or Index of Forbidden Books was really a series of indexes issued by the pope or by the Congregation of the Index from I 559, the date of the first Index, until 1966 when the Church decided that the Index should no longer be considered an instrument of censorship but should be relegated to the status of an historic document. ${ }^{2}$ Ideally the concept of the Index remained unchanged for the four hundred years it was observed: it was to be "the authoritative guide by which practising Roman Catholics ... had to regulate their readings." ${ }^{3}$ The Index Librorum Prohibitorum was not the sole means of censorship used by the Church but its duration across centuries, the extended geographical area to which it was applied, and its visibility as a tangible historical artifact have made this printed list the best known one.

The Roman Catholic Church has always considered itself as ". . . the custodian of divine revelation ... whose duty it was to interpret the teachings of Christ." Acceptance of this position, at least among Catholics, "supported the whole structure of the Church's control of literature." As support for its authority to claim the power of censorship, reference was frequently made to the burning of books at Ephesus, as described in Acts XIX. Then fervent converts of St. Paul cast books of magic and the occult into the flames, burning them in public testimony to their potentially damaging nature. Centuries later the Inquisition followed their example.

The early Church occasionally issued prohibitions on reading matter, but this was done on an individual basis. The Acta Pauli, an historical romance, was prohibited in I50 A.D. although it continued to circulate among Christians for several centuries. Over the next several centuries, works by leaders of a number of heretical movements were forbidden. In 325 the Council of Nicea prohibited the Thalia of Arius; the Emperor Constantine ordered the destructions of the writings of Porphyry and Arius, making death the penalty for the concealment of copies. The works of Origen were forbidden by the Council of Alexandria in 399; the works of Pelagius prohibited by Innocent I in 402; the writings of the Nestorians were condemned by the Council of Ephesus in 435;

2 "The Index," The Christian Century, I I May i 968, p. 608.

${ }^{3}$ S. H. Steinberg, Five Hundred Years of Printing (Baltimore, Md.: Penguin Books, 1955), p. 179 .

${ }^{4}$ Raymond A. Burke, What is the Index? (Milwaukee, Wisconsin: Bruce Publishing Co., 1952 ), p. 3 . 
Manichean books were ordered burned by Theodosius in 436 . The first "papal" indexes were issued by Gelasius I in 494 and 496 . While the Index of 494 was concerned only with the public and official reading, the Index of 496 catalogued the Patristic writings approved by the Church as well as those condemned as either apocryphal or heretical. However, unlike later indexes, the latter index did not prohibit the reading of the works, it only called for their rejection and condemnation. Other examples of early censorship could be cited; however, the number of examples is small since the restriction of literacy during this period meant that literature was not a serious threat to most believers. ${ }^{5}$

But by the fifteenth century the invention of printing and the appearance of books in greater number forced the Church to develop a more effective system of control. Because of the large quantity of books being printed, many of them by authors designated as heretics (Protestants), the condemnation of individual works became impractical. The Church spent much of the fifteenth century trying to institute a more comprehensive and effective method of censorship. In I 50I Pope Alexander VI first tried to institute a uniform system of censorship throughout Europe by making censorship the duty of local ecclesiastical authorities, requiring them to censor both theological and nontheological works. Although the printers of Cologne protested against this attempt to extend clerical authority beyond control of heretical works, they did not succeed in winning their point. Alarmed by the success of the Protestant Reformation and fearful of its larger implications, local ecclesiastical authorities responded by issuing a number of indexes. ${ }^{6}$ The first of these lists, which totaled seventy titles, was published by Giovanni della Casa in Venice in $1549 .{ }^{7}$ Casa, who played a major role in the Roman Inquisition, was an assistant to Cardinal Carraffa, later the compiler of the first papal Index. Longer lists were also issued in Florence in 1552 and in Milan in I 554. Finally in I 559 Carraffa, then Pope Paul IV, issued the first general Index Librorum Prohibitorum. This catalog was first published by Antonio Blado who had been appointed Tipografo Camerale, or printer to the Holy See, in $1549 .{ }^{8}$

\footnotetext{
${ }^{5}$ George Haven Putnam, The Censorship of the Church of Rome and Its Influence upon the Production and Distribution of Literature, 2 vols. (1906; rpt. New York: Benjamin Blom, Inc., x 967 ), I, 55-63.

${ }^{6}$ Steinberg, p. 178.

T Putnam, I, I 7 I, 48 I.

${ }^{8}$ Steinberg, p. I $78, \mathbf{1} 53$.
} 
Because the first Index was quite severe in its proposed criteria for condemning books, it met with only a very limited acceptance. Forbidden books included all works written by heretics, all books without identifiable authors or printers, and all books printed by heretic printers regardless of the nature of the book. Also forbidden were works specifically condemned by title and works of ". . . aeromancy, cheiromancy, physiognomy, geomancy, hydromancy, oneiromancy, necromancy, divination, magic, or astrology." Because Talmudic books also were placed on this list, over I 2,000 volumes of Talmudic books were burned in Siena alone; all discoverable editions of the Talmud in Venice were burned in the Piazza San Marco in $1553 .^{\circ}$

The format of this Index was changed but carried over to subsequent indexes. The original division of the Index was into three categories: all works (even future) of heretical authors; condemned works written by known authors; condemned books written by anonymous authors. Later editions of the Index revised the schema by arranging authors together in alphabetical order and then indicating the status of their works. "Opera omnia" continued the first category or else the title of a specific work was provided. Later when morality became as much a matter of concern as theology, the citation "Omnes fabulae amatore" meant that all love stories written by an author were off limits. ${ }^{10}$

The Pauline Index is notable not only because it served as a model for all later papal indexes, but also because the Church recognized printers and publishers, as well as authors, as subject to its control. Through issuance of these guidelines, the Roman authorities showed that they intended to keep the surveillance of reading in their own hands. Yet in reality, this task passed under control of local secular and ecclesiatical authorities because they carried out the enforcement of the Index. Because of its restrictive nature, especially in its denial of permission to read many books considered essential to scholars of the time, this Index met with a great deal of resistance. After Paul's death many of the prohibitions were relaxed and soon afterwards a need for a revised Index became apparent. ${ }^{11}$

Therefore, in 1564 a new papal Index was promulgated jointly by Pius IV and the Council of Trent as part of the reforms undertaken by the Church during the period referred to as the Counter Reformation.

${ }^{9}$ Putnam, I, 74, I 72-I 73.

10 Burke, p. 51 .

11 Putnam, I, $175-177$. 
This Index made the grounds for prohibition of titles much more specific, exempting many previously condemned works. For example, works by heretic authors which did not treat religious subjects were permitted, unless written by dissident leaders like Luther and Calvin. The most important feature of this Index was "The Ten Rules" which listed categories of literature to be avoided and which were to serve as a guide for all future censors. These rules were repeated in most of the following indexes. Although the focus of this Index remained on controversial theological doctrines, a new emphasis on moral behavior appeared. Rule VII forbade the reading of obscene literature on the grounds that it would would corrupt a reader's morals. However, because of the beauty of their language, classical texts were exempted from this rule as long as they were read only by adults. ${ }^{12}$

This Council also created a permanent agency, the Congregation of the Index, to monitor and periodically revise the Index under the supervision of the pope. Formally established in $157 \mathrm{I}$, it persevered in its mission, performing the same functions even after its merger with the Congregation of the Holy Office in $1917 .^{13}$

While the Pauline Index had had only a limited effect on the intellectual life of Europe, the Index of Trent was implemented ruthlessly. Although in the end the enforcement of the Index still rested with local authorities, Pius IV's successor, Pius V, was by temperament an ascetic and a relentless reformer who inflamed others with his zeal. As pope he sharpened the rules of the Inquisition in order to stamp out heresy wherever he thought it appeared. During his reign, the Inquisition pinpointed definite objects of attack with visible results. "... [No group] . . . was pursued more relentlessly than the intellectuals, among whom many of the Protestant doctrines found acceptance. Princes and states withdrew their protection of heretics." ${ }^{14}$ Under Pius V the Church wielded the power it claimed.

Although these early indexes stand out as milestones in the Church's program of censorship, the exact nature of later indexes is more difficult to decide. Different scholars provide different lists of new editions of the Index, for distinguishing between reissued and revised lists is a confusing task. Clearly however, the issues of the following dates were thoroughly revised: the Index of Sixtus V in I 590; the Index of Clement

12 Putnam, I, i 8 I- I 93.

13 Burke, p. 8.

14 "Pius V: Saint and Pope," Encyclopaedia Britannica, I 979 ed. 
VII in I 596; the Index of Clement X in 1670 ; the Index of Innocent $\mathrm{XI}$ in $\mathrm{I} 682$; the Index of Benedict XIV in $\mathrm{I} 758$; the Indexes of Gregory XVI in 1835 and 1841 ; the Indexes of Pius IX in 1865 and 1877 ; the Indexes of Leo XIII in I $88 \mathrm{I}$ and I 900 ; the final Index issued in $1948 .{ }^{15}$

The Index of Clement in 1596 merits attention because it reflects a change in emphasis in the Church's censorship policy. It points to a recognition of the fact that due to the continual expansion of book production, the Church could not hope to supervise the literary production of the world, but would have to define a more limited scope of activity. In this Index the Church was more concerned about scrutinizing writings of Catholic authors than the works of heretical authors on the assumption that Catholics were more prone to read the former than the latter. The Clementine Index was more widely distributed than any prior Index other than the Index of Trent. ${ }^{16}$

The Index of Benedict XIV in 1758 moves even further in the direction of trying to create a more manageable list of books. Earlier efforts to keep track of new publications through booksellers' lists were acknowledged as useless, for they led to lists full of bibliographic errors and placed books on the Index on the basis of educated guesses. No body of men could have hoped to read all the books produced; instead, logic demanded a restriction of the list. Therefore, the Benedictine Index promoted the policy followed in subsequent indexes of making condemnations of general categories of books either by class or subject. ${ }^{17}$

Following indexes were less an effort to implement new policies than attempts to keep the listing current. Despite attempts to limit the scope of the Index, the largest number of titles was added during the seventeenth and eighteenth centuries. In the eighteenth century the hostility between the major writers of the Enlightenment and the Church added many titles written by philosophes to the Index of 1758 and its revisions of $\mathrm{I} 765, \mathrm{I} 770$, and $\mathrm{I} 779$. In the light of Voltaire's motto, "Ecrasez l'infâme," and his reluctance to distinguish between religion and superstition, it is not surprising that his works, as well as those of Rousseau, La Mettrie, d'Holbach, Marmontel, Raynal, Diderot, and d'Alembert, were prohibited. ${ }^{18}$

In the nineteenth century, even though the influence of the Index was waning, the names of many novelists, among them Stendhal, Sue,

\footnotetext{
15 Putnam, II, 48 I-482; I, 60-62.

16 Putnam, I, 253.
}

17 Putnam, II, 54-6o.

${ }^{18}$ Putnam, II, 80-81. 
and Zola, were added to the list. The addition of Laurence Sterne's $A$ Sentimental Journey, published a century earlier, underlined the inability of the Congregation of the Index to be knowledgeable of book publication on a world-wide scale, especially in Protestant countries. For the same reason, Locke's works also were not added to the list until the nineteenth century. By this time, the Index was not meeting its declared purpose of providing consistent supervision of publications; by the century's end, the list showed quite a disproportionate number of titles of love stories and of titles in the Italian language. ${ }^{19}$ No wonder then that by the nineteenth century, the Index was almost totally disregarded by all but the most devout Catholics or those in the Church's hierarchy. ${ }^{20} \mathrm{By}$ I 900 one priest could note that he believed the Index had little effect on actual reading habits because people often did not realize a book had been prohibited and dispensations to read prohibited books were easily obtained. ${ }^{21}$

The twentieth century has had little to add to the history of the Index, except to show that Church policy has been changed to register a more accurate assessment of the status of the Index in the world. Since 1900 the trend had been to reduce the number of formally condemned books; the Index of I 948 showed that only 255 titles had been added to the list during the first half of the century. ${ }^{22}$ In 1966 the endless task of compilation was recognized as an unnecessary one: the Index was formally abandoned.

Officially, the Index was abolished because of a new articulation of Church policy, not because it was rarely consulted or followed. As part of the wide system of reforms undertaken by Vatican II, the Holy Office (formerly "of the Inquisition") became the Congregation for the Doctrine of the Faith. Its primary mission became to foster theological research and to strengthen relationships with Protestant and other humanistic movements. Given the principle of Vatican II that ". . . freedom of religion and philosophy ... [is] the most fundamental right of man ..." the Index logically was viewed as an historical relic. Therefore, in I 966 the Index Librorum Prohibitorum lost the authority that had been attributed to it for centuries, becoming no more than a moral guide or historical document. ${ }^{23}$

\footnotetext{
19 Putnam, II, 403-4II.

${ }^{20}$ Steinberg, p. 212.

21 Putnam, II, 444.

22 Burke, p. 5 I.

23 "Canon Law," Encyclopaedia Britannica, $1979 \mathrm{ed}$.
} 
Yet even this relaxation of control was qualified. Cardinal Ottaviani who announced the decision stressed that the authority of the curia to evaluate literature was not being abandoned, but was merely being transferred to the Church's various national conferences. ${ }^{24}$ Such a transferral was possible because ". . . the Council 'has recognized in Catholic laity a greater maturity ... [ [which deserves a] role of greater responsibility in the Church.' " $\mathrm{He}$ also noted that the ban on reading Communist publications was still in effect. ${ }^{25}$ Despite his qualifications, the radical nature of this departure from the Church's previous position emerges from a comparison between the determination behind the Church's earlier efforts to enforce the Index with its refusal to prohibit the reading of the works of a contemporary theological rebel, Hans Kung.

In reviewing the history of the Index, a measure of the Church's desire to enforce its censorship might be found in the amount of energy it invested in forcing obedience to the Index, rather than the extent to which reading of prohibited books was actually restricted. The Church simply did not have enough manpower to make its censorship totally effective, but its restrictions were more than just annoyances. While the effectiveness of the Index varied according to time and place, it did influence the history of book production and distribution, and the reading habits of Europe. The Inquisition tried to control book production either by requiring prepublication approval to print or by the seizure and burning of books printed without prior permission, the titles of which were often to be found on the Index. Book smuggling and other deceptive practices resulted from attempts to outwit the censors, although the burning of books, torture, excommunication, and death were the prices paid upon discovery of these practices by the censors. For example, in Holland after the 559 Index was published, many Dutch printers were frequently accused of violations and were sent to the stake for publishing Protestant books. To protect themselves Dutch printers began to use false imprints on their books. ${ }^{26}$

Writers also tried to circumvent censorship. In France, Pascal published his Lettres Provinciales in a circuitous fashion. First published separately and clandestinely between January 23, I656 and March 25, I657, they were finally published together as one work, but under the

\footnotetext{
24 "The Index," The Christian Century, i I May 1966, p. 608.

25 "The Index R.I.P.," Commonweal, 6 May i 966 , p. 193.

26 "Publishing History," Encyclopaedia Britannica, r 979 ed.
} 
fictitious name of Louis de Montalte. Through Jesuit influence this Jansenist work was soon placed on the Index and ordered to be burnt. In Italy La Vita di Benvenuto Cellini, actually published in Naples, was issued with the imprint "Colonia" in an effort to mislead ecclesiastical censors. ${ }^{27}$

Also in Italy, Galileo's observations on sunspots "Istoria e dimostrazione alle macchie solari e loro accidente" lent enough credence to Copernican theory to appear threatening to the Church, which derived its astronomy from the Scriptures and the works of Ptolemy. To prevent further challenges to Ptolemy's theory, the Church placed Copernicus' works on the Index after 1616. Although Galileo allegedly was forbidden to support or discuss Copernican theory again, his works were not placed on the Index. However, in 1632 he published "Dialogo sopra i due massimi sistema del mondo, tolemaico e copernicano" in which theoretically he merely described the two systems but supported neither. Evidence suggests that Galileo's earlier agreement not to discuss Copernican theory was a conveniently forged document. If so, he may not have realized the dangerous position he was placing himself in, although he did try to protect himself to some extent through use of a sophisticated stratagem. Even under the guise of objectivity, his preference for Copernican theory was too evident to be ignored. Galileo was tried as a suspected heretic, forced to recant his views in public on his knees, and then sentenced to his estate for the last eight years of his life. ${ }^{28}$ The Church was not anxious to ally itself with the advance of modern science.

The above examples are not isolated instances of the Church's effort to control or of reactions generated by this effort. Although perhaps never as powerful as it claimed to be, the Church did force local ecclesiastical and secular authorities in Catholic countries to at least recognize its authority, sometimes not without a struggle. The Church was dependent on local authorities to carry out its wishes, and even if those authorities did not actively cooperate, they did not openly flaunt the papacy.

In France, the power struggle between church and state began early and openly. One of the earliest of French printers, Robert Estienne, antagonized ecclesiatical censors at the Sorbonne. Although theoretically

\footnotetext{
${ }^{27}$ Exhibit, "European Drawings [and Books], 1375-1825." (New York: Pierpont Morgan Library), i 9 Feb.-3 May $198 x$.

28 Abbé Leon Garzend, L'Inquisition et l'hérésie (Paris: Desclée, de Brouwer et Cie., I 9 I2), pp. I-23.
} 
they were the king's censors as well, Estienne on several occasions sought royal protection, fleeing his home and going to live at the court of Francis I. Obviously, Francis could not control the ecclesiastics outside of his immediate domain. But even with the power of Rome behind them, the Church in France could not prevent the publication of works, particularly the translations of the Scriptures, that it deemed heretical..$^{29}$

This battle in France for control of publishing continued into the eighteenth century when the Encyclopédie of Diderot and d'Alembert reached every corner of Europe in spite of the fact that it was placed on the Index of I 759. The Encyclopédie, the major publishing venture of the Enlightenment, was openly hostile to the Catholic Church. Afraid to attack the Church openly in the logical entries such as "Christianity," the philosophes placed their attacks in more obscure articles less likely to be read by the censors. "The Encyclopedists draped the pope in Japanese robes before mocking him in SIAKO; they disguised the Eucharist as an extravagant pagan ritual in Y PAINI; they dressed up the Holy Spirit as a ridiculous bird in AIGLE; and they made the Incarnation look silly as a superstition about a magic plant in AGNUS SCYTHICUS." ${ }^{30}$ In spite of these rather transparent precautions, the response to its publication was immediate. The Encyclopédie was attacked by all members of the religious establishment: the Jesuits, the Jansenists, the General Assembly of the Clergy, the Parlement of Paris, the King's Council, and the pope. On March 5, I 759 Pope Clement placed it on the Index and in September he ordered that owners of the Encyclopédie must have their copies burned by a priest or face excommunication. Considering the amount of money invested in their purchase, few owners were likely to have followed this directive. The Encyclopédie was able to survive in the face of pre-publication censorship attempts because of powerful friends at court who guided it through the hazardous shoals of publication by resorting to legal and illegal chicanery. Papers were protected from seizure; the text was published under a changed title; and in 1775 , the last ten volumes were issued under a false imprint, "A NEUFCHASTEL/ CHEZ SAMUEL FAULCHE \& Compagnie, Libraires \& Imprimeurs." Despite formal condemnation of the work, the distribution and readership of the Encyclopédie was universal, with sales in Lon-

\footnotetext{
${ }^{29}$ Putnam, II, I 6.

${ }^{30}$ Robert Darnton, The Business of Enlightenment (Cambridge, Mass.: Belknapp Press, 1979), p. 8.
} 
don, Amsterdam, Brussels, Paris, Lisbon, Madrid, Naples, Venice, and beyond. In France many of the buyers were priests in the provincial parishes. ${ }^{31}$ Therefore, the conclusion must be that even before the Revolution, the enforcement of the Index in France and cosmopolitan Europe was not very effective. Once published, a book would reach its audience.

In neighboring Spain, the Church's efforts to enforce censorship were more vigorous and more effective. Even before the first papal index was issued, the Spanish Church had issued local lists of forbidden books. If the Inquisition took a more virulent form in Spain, it was due to the Inquisition's fear of the relapse of numerous Jews and Mohameddans who were recent converts. The Spanish Inquisition accepted the Index of the Council of Trent but went further in its censorship, prohibiting additional books while at the same time allowing books condemned by the papacy. From the mid-seventeenth to mid-eighteenth centuries both the papacy and the Spanish Church claimed jurisdiction over Spain, but control really rested with the Spanish Church. In Spain, different in this respect from other countries, members of the Inquisition were not appointed by Rome, but by the Spanish Crown, who claimed their allegiance. ${ }^{32}$ Testifying to the zealousness of the censors in Spain is Townsend's description of its results as witnessed by him during his visit in the late eighteenth century.

At Barcelona, in the convent of the Dominicans, there is one apartment filled entirely with books prohibited by the Inquisition and, in order that no one may be tempted to peruse them, all the vacant spaces are filled with devils cracking human bones, it is supposed to be of heretics. Lest, however, this sight should not suffice to check a prying disposition, they are well secured by lock and key, and no one has access to these writings without a special license. ${ }^{33}$

The earliest books on the Spanish lists were written by heretical authors, but by the eighteenth century fear of French intellectual influence had added the names of the French authors, Jansenists and philosophes among them, to the lists. Still, even with the strong sanctions taken against violators, Spain was removed but not isolated from the intellec-

\footnotetext{
31 Darnton, pp. 9-13, 299, 323.

${ }^{32}$ Marcelin Defourneaux, Inquisición y censura de libros, en la España del siglo XVIII (Madrid: 'Taurus Ediciones, I 973), pp. 26-34.

${ }^{33}$ Townsend, Travels in Spain, as quoted by G. Coulton in Inquisition and Liberty (1938; rpt., Boston: Beacon Press, 1959), p. 325.
} 
tual ferment of the rest of Europe. ${ }^{34}$ And the censorship that did occur there was not controlled by Rome and did not result directly from indexes issued by Rome.

If in other parts of Europe the papacy's attempts at censorship met with limited success, the Republic of Venice finally succumbed to them to a much greater extent. Considering that Venice was one of the major centers of European publishing and distribution, censorship there had ramifications all over Europe as well as a devastating economic effect on the Venetian book trade. Even here, however, the Index was enforced stringently for less than thirty years. Because initially the leaders of the Republic were not convinced that heresy was a serious threat, the bookmen were able to resist early papal attempts to impose censorship. But by the I 560's the Republic shifted its position because of a growing number of conversions to Protestantism among the noble youths of the city. Resistance to the Inquisition also diminished because members of the Venetian government were allowed to participate in it and to be present during the trials of its victims. From I 570 to the early I 590's when the Index was enforced, the printing of prohibited titles almost ceased. Surprise raids on booksellers to check their stocks limited the distribution of illegal copies and brought financial distress to bookmen whose inventories were seized.

Yet even in the worst of times the justice of the Venetian Inquisition was tempered. The Inquisitors seemed to favor expedient justice: those who confessed quickly had their cases settled quickly, paid a fine, and were not pressed for additional information. In the cases of bookmen in particular, the Inquisition seemed to have had quick convictions and the burning of the offending copies as its main purpose. Because the court was easily satisfied, bookmen would plead ignorance of the system of distribution by which the illegal books were acquired. Judgments were more severe when those who refused to confess were convicted or if the booksellers were suspected of holding heretical views. Probably the Inquisition used torture to extract confessions in only 2 to 3 percent of the cases. Only fourteen victims received death sentences during the sixteenth century; this penalty may have been avoided because the Republic wished to avoid antagonizing the Protestant states with which it traded. Furthermore, the death sentences were carried out in a manner calculated to

${ }^{34}$ Defourneaux, pp. 34, 213-2 15. 
avoid unpleasant publicity. Victims "disappeared" from prison in the middle of the night, were bound and gagged, taken out to sea, and dropped overboard. ${ }^{35}$

Even though the Index was enforced, the "light" penalties for its violation encouraged the Venetian bookmen to engage in a lucrative smuggling trade, undaunted by the presence of the Inquisition's representatives in every customshouse. The smuggling network must have been quite extensive; trade ties with many Protestant countries and the determination of the bookmen not to give evidence against each other encouraged its growth. The prices paid for smuggled books suggest they were readily available, not rare commodities. Most popular were books on the occult, Protestant translations of the Bible, and biblical commentaries. Sometimes these works were sold quite openly with false title pages, getting even the best-intentioned of men in trouble. One Franciscan monk was censured for having bought an Erasmus New Testament from Francesco Ziletti, a major bookseller and perhaps a key figure in the smuggling network. The monk's copy identified its author as "Theodore Bèze."

Despite the large number of illegal books entering the Republic, only one bookman, Pier Longo, received a death sentence for smuggling. At his trial, damaging testimony given by a publisher who had traveled with Longo indicated that Longo had many suspicious associations with Protestants. The suspicion that he, too, was a Protestant probably accounted for the harshness of his sentence: he was secretly drowned at sea on the night of January 3 I, I 588 . Even his death did not change the attitudes of the bookmen towards the Index, and eventually, by the end of the century, the Republic also withdrew its support from Church censorship. Stiff competition from newer centers of publishing, including Rome, and the weakened condition of the Venetian Press made the Republic worry more about economics than religion. The alliance between Rome and the Republic dissolved, never to be re-instituted in a serious manner. In the seventeenth century the Index was openly ridiculed by Venetian bookmen. ${ }^{36}$

These examples of the effect of the Index in three different countries show that while the control of the Church over reading varied enormous-

\footnotetext{
${ }^{35}$ Paul F. Grendler, The Roman Inquisition and the Venetian Press, $1540-1605$ (Princeton: Princeton University Press, 1977), pp. 53-60, 82.

${ }^{36}$ Grendler, pp. I 83-188, xx-xxi.
} 
ly over time and in different locations, the Church could never impose an entirely effective control even in Catholic countries, although it was most determined to do so. Lacking the manpower and complete authority to carry out its goals meant dependence on the local secular or ecclesiastical authorities who were often less than fully cooperative. Thus, the determination of the Church to regulate the printing, selling, and reading of books was often frustrated. By the nineteenth century when local authorities did recognize the authority of Rome, they often did not have the power to enforce their supervision. By then the laity often did not recognize the authority of the Index. Even if they had, the Church did not have enough readers to evaluate the increasing number of books coming off the presses. To compound the problem, most of the members of the Congregation of the Index were Italian ecclesiastics who were most comfortable when directing their censorship at books written in Italian. Publications in other languages were neglected..$^{37}$

By the twentieth century the Index had become outmoded and parochial, a rather useless appendage, respected but not observed. If at the height of the Counter Reformation it had only been able to hamper but not eliminate the reading of forbidden texts, what possibility existed that it could control-or even catalog-the flow of literature pouring off modern presses in secular states? And perhaps the supervision of reading may be considered less necessary now because of the fact that the sheer number of books has changed the influence of every individual book. In our era, partly due to the competition from other media, books have become a less incendiary form of communication, at least in western societies. Also in our times, the Church has been forced to recognize that the threat to its existence comes less from any danger within western society than from political powers beyond the boundaries of its influence.

The Church's new policy of toleration may represent a true philosophical change, but it also represents a shift in political realities. It is in the Church's best interest to support the values of the liberal secular societies upon whose existence its own existence depends. As the Church lost ground as a political power, it tried to assume a power of persuasion and moral authority to unite Christians against atheistic totalitarian states. The Church would not wish to be identified with those repressive societies which employ censorship and fear as a means of their survival.

${ }^{37}$ Putnam, II, 479. 
Therefore, in order to survive in the modern world, the Church has had to preach and believe in the necessity of tolerance and reconciliation. Hence the principle that "... freedom of religion and philosophy . . . [is] the most fundamental right of man" embraced by Vatican II defines a logical position for the Church to hold, even if it is not the traditional one.

In recent years the controversy surrounding the Vatican's inquiry into the writings of Hans Kung demonstrates the more liberal attitudes of the present Church. Hans Kung is a Swiss theologian who until recently was attached to the Roman Catholic faculty in theology at the University of Tubingen in Germany. In his books, which include Justification (1957), Reform and Religion (1962), The Church (1967), and On Being a Catholic ( 1977), as well as in his journalism, Kung has argued for a radical revision of the Church's structure and doctrine as they now exist. For example, he has refused to accept the idea of the virgin birth, the divinity of Christ, and the infallibility of the papacy. ${ }^{38}$ Whether Kung's views reinstate an earlier vision of Catholicism or advocate an unadmitted form of Protestantism is not at issue here. Kung claims to be a true Catholic, but the Church disagrees with him. Given this disagreement, the Church's reaction to Kung's divergent views is extremely interesting. According to one observer the Church has been reasonable and benevolent in its attitude towards Kung. The Church has not attacked the existence of Kung's writings by banning them, nor has it denied that Kung is a Catholic; it merely has said that Kung must not represent himself as a spokesman for the Church. ${ }^{39}$ In 1979 the Vatican withdrew the privilege of teaching from Kung. Kung still teaches at Tubingen, but he is no longer attached to any theological faculty, which places him in a peculiar position within the University.

A less generous observer notes that although Kung has not been excommunicated and his books have not been banned, he faces a new type of isolation, one similar to that faced by authors whose books used to be placed on the Index. For Kung has now become a philosopher without attachment to a community; he will not be able to turn to his peers for support. Furthermore, since his courses will not count towards any degree, he may eventually lose his audience of the next generation of theo-

\footnotetext{
${ }^{38}$ M. Novak, "Behind the Kung Case," N.Y. Times Magazine, 23 March 1980, p. $34^{+}$.

${ }^{39}$ Novak, p. 34 .
} 
logians. His ideas will not be taught to students at other universities for the obvious reason that no jobs will be given to the graduate students whom he has directed. Most importantly, now that his works have been dismissed as "interesting" but not representative of Catholic thought, Kung will be banned from speaking at Catholic conferences. ${ }^{40}$ The Kung case raises the provocative question, "How much freedom of philosophy and religion is being accorded to Kung?"

Still, the Church's reaction to Kung does seem to be a more civilized and sophisticated way of handling dissidence than the burning and excommunication that would have been the response in an earlier era. In an age where the Church is trying to improve ties with other faiths, it would be self-defeating to attack publicly a member for holding views similar to those held by rival faiths with which it is seeking rapprochement. Better public relations will be maintained by diffusing the issue quietly. Finally, the Church is trying sincerely to be more understanding of other viewpoints than in the past, even when it rejects them.

Like any institution that exists over a long period of time, the Church has had to adapt and change with changing circumstances. The history of the Index Librorum Prohibitorum reflects the Church's varying responses to different historical crises. Threatened by the results of a new technology, the Church attempted to control it; when the printed word became too commonplace a medium to sustain its original impact, the Church could relax its defenses and relegate the Index to the status of an historical document. This action did not mean that the Church would abandon its efforts to keep order within its ranks, even if order comes at the expense of freedom of expression. While the Church's attitude towards dissent is much more liberal than in the past, many observers will note a discrepancy between the principle enunciated at Vatican II and the Church's recent actions.

${ }^{40}$ John J. Carey, "Hans Kung and Tubingen: Compromise and Aftermath," Christian Century, 13-20 Aug. 1980, pp. $791-796$. 
